\title{
Sociocultural context of gender-based violence in local societies
}

\author{
Lida Kurbanova $^{1 *}$ Raisa Tagirova ${ }^{1}$, Salambek Sulumov ${ }^{1}$, and Zara Umarova $^{2}$ \\ ${ }^{1}$ Chechen State University, 364024, Grozny, Russia \\ ${ }^{2}$ Grozny State Oil Technical University, 364051, Grozny, Russia
}

\begin{abstract}
The concept of gender-based violence takes into account the dominant significance of specific sociocultural phenomena - masculine and feminine styles of existence in specific traditional societies. This sociocultural context provides an additional notion to the gender-based violence in family, "legitimizing" it in a way. Several researchers study the scale of gender-based violence within modern societies as a consequence of the hierarchical construction of gender relations (Brückner, 2006). In traditional cultures, the gender hierarchy is also regarded as sacred and serves as the basic component of the attributive gender practices of male and female daily life. The article analyzes the causes of gender-based family violence by man over woman in a local society such as Chechen, wherein the normative etiquette of the Adat (oral law), on the one hand was extremely disapproving of such practice of man's manifestation of his power in a family. It should be noted that there has existed a hierarchical subordination of woman to man in the Adat, however, at the same time, any type of male violence against woman had negative connotations in the public consciousness while characterizing a man as a social unit. The man's code of honor "Khonahalla" symbolized, along with other sets of valuesand the power over his wife. On the other hand, it would exclude the possibility of physical, psychological and moral violence against her. The article discusses the reasons for the increasing practice of gender-based violence within the Chechen society, in the context of socio-political and cultural transformations of the latest 10-15 years. Specific difficulties of institutional protection of women exposed to domestic violence under these conditions have been studied. An analysis of a subjective assessment of gender-based violence by women themselves has been made on the basis of in-depth interviews among the 5th year female students of Chechen State University. (N17). As a result, we have come to the conclusion that the key causes of the deformation of value bases of family and the increase of gender-based violence against women are problems of the institutional transformation of social and legal institutions in the
\end{abstract}

* Corresponding author: medna59@mail.ru 
Chechen society, especially: the violation of steady value norms of the Adats; - simultaneous strengthening, poorly reflected by the society, of Sharia norms, - the peripheral place of the Russian legislation in familymarriage relations.

\section{Introduction}

Gender-based violence is a social phenomenon, complex, and multidimensional in its structure. In the mass consciousness, it is often reduced to a stereotype being purely a physical abuse of woman by man, but this is a narrow, one-sided approach. In fact, genderbased violence in any society is a sociocultural category, primarily because of its motivations and consequences. The gender-based violence, being universal, exists in various forms in almost all spheres of life: political, economic, spiritual, and family. Thus, this phenomenon has always been a central problem of the institution of family, its social well-being, especially in the context of the transformation of its role-playing and attributive practices. Any type of domestic violence is a reflection of the complex social and economic transformations of a society wherein a person with his or her misfortune is often left alone. The private life of a person is a delicate and sensitive area of human relationships. If a society does not develop steady and functioning social mechanisms for the protection (of the victim), domestic violence becomes a source of social tension, manifested in the lack of pledging of security for both the physical and psychological as well as the economic and social spaces of a person.

If the American and Western societies, with their properly functioning democratic institutions of the legal system, are trying to solve the problem of gender-based domestic violence through systems of legal control over an abuser (Laktionova, 2010), then within traditional societies, a family and the world of its communications are embedded in the normative practices of customs and traditions, which largely determines the sociocultural burden of gender relations. Among most problems of the family institution, the genderbased violence is one of the controversial and taboo problems in the Chechen society. It is coincidence that social services, NGOs of the republic, legal bodies, reports of representatives of departments, sociological polls indicate an increased social tension in families due to the frequent cases of domestic violence over the past 10-15 years.

The aggravation of this problem in public discourse is caused, in our opinion, by the discrepancy between the declarative traditional gender norms (physical violence is not welcome in the Adats) and latent attributive practices of actually existing gender-based violence. The conclusions of sociological studies within the republics of the North Caucasus (Sirazudinova, 2017) indicate this contradiction. The abovementioned factors bring the problem of domestic violence to the forefront and require its theoretical analysis and interpretation.

The purpose of the article is to reveal the specific causes and ways of functioning of gender-based violence in the traditional Chechen society, which we tried to achieve by solving the following tasks.

1) to give a theoretical analysis of gender-based violence as a sociocultural phenomenon in local societies;

2) give an analysis of the subjective assessment of gender-based violence based on a survey in the focus group of the 5th year students (girls) of Chechen State University (N17) and to indicate the correlation with axiological sets in public opinion on domestic violence as a social phenomenon. 
3) to reveal the causes of institutional instability of legal, religious, social institutions in an attempt to solve the problem of gender-based violence in the family.

\section{Working hypothesis}

The weak functioning of steady, non-contradictory, legal institutions, both traditional and formal, triggers social insecurity of a woman during domestic violence.

Also the strengthening of traditional institutions of law within the Chechen society, which are formally designed to regulate the standard framework of the institution of family and marriage, within the studied problem, are mainly of recommendatory nature. The inability to implement legislation in the Adat and Sharia often complicates the solution of the problem of gender-based violence in the family.

\section{Subject of research}

Given that the definition of "Gender-based violence" includes a whole range of violent interaction (husband-wife, brother-sister, father-daughter, father-in-law, etc.), as well as types of violence (Anisimov, 2016) we shall define the scope of the problem within the framework of the husband-wife interaction subsystem.

Only psychological and physical abuse shall be considered. Exactly these types of violence are most frequently articulated by informants during interviews.

\section{Research method}

The basic theoretical construct for our analysis of gender-based violence within the Chechen society was the ethnomethodological method of G. Garfinkel. (Garfinkel, 2002). In contrast to the socio-constructionist phenomenological sociology, Harold Garfinkel focuses on radical phenomena and various ways in which they are interpreted. According to the American sociologist, people's social actions are loaded with a kind of "background", cultural meaning, explanatory model, and interpretation which is based on tradition or religious standards of a particular community of people. The discourse of a patient woman who is trying to save the family while living with the abusing husband preserves a positive connotation in public consciousness although the very gender-based violence in the family is highly condemned.

Violence, like any other social action, is a part of people's lives. If the estimated background of violence in society renders this social action as unacceptable, there is a possibility to reduce in the family.

\section{Sociological survey. Interview method}

Among the interviews there were confessions from 17 young women, 9 of them at least once have suffered from physical violence, 13 experienced different types of psychological violence (insults because of her, mental abilities, insults addressed to her relatives, reproaches over sponging). (The in-depth interview was conducted among the 5th year female students of the correspondence department of the Faculty of Law (specialty "social work") in January-February 2018. 
We provide only excerpts from some of the interviews due to the limited size of the article.

\section{Milana, 24. Divorced.}

-She got married for love. At first everything was fine. Then he began to communicate with other girls on the phone. When I rebuked him, he hit me for the first time. It was 4 months after the wedding. I was very hurt and offended. I warned him, if you hit me once again, I will go away. But then other problems started. I was not allowed to go out, even use public transport, only if with him in a car. I was not allowed to walk in the city, neither was I allowed to work because my pennies wouldn't make any difference. No makeup. It lasted for two years. I could not take it anymore and I left. He has been running after me for 6 months begging to return, and says that he understood everything.

- Will you come back? - Never, under no circumstances. It is good that we had no children.

But not all girls come to such conclusion. The survey indicates that the institution of public opinion continues to be the most important external locus of control. If there is no physical violence, there is a roof over your head, you live in material wealth, all other arguments are not very convincing and are considered as far-fetched whims. Parents of women are often under the influence of these stereotypes. In such a closed social circle, a woman finds herself at dead end.

\section{Selima, 21. Married.}

-What do you consider a pressure from your husband? Some find justification in Islam for this behavior of the husband. Don't you think so?

Well, it's scary. I am young. I am not allowed to chat in social networks. On my birthday party we let the balloons up and my fellow male student was standing next to me, after I showed the pictures to my husband, there was a scandal. He says, "Why is he standing next to you? That's what you are doing under the guise of studying."

-What do you mean?

-. A man should not stand near a girl. I do not understand what I am guilty of. I am pregnant now, there is nothing that pleases me in marriage, shall I leave? My relatives said that this was not a reason for divorce. Be patient, since you got married.

The 3 out of the 9 women who were subject to physical violence at least once, lived constantly under fear, but their families where they had grown up, were quite decent.

Few women are able to tolerate a constant physical abuse. Psychologists state that the formation of a woman's psycho-type, who can live under constant fear, occurs long before the violence itself. It can be rooted in the victim's own family. My interviews did not always confirm this thesis.

\section{Amina. 22. Married.}

-Why are you tolerating humiliation, you do say that insults and beatings occur almost every week.

- I have left him several times, he is still asking to return, and he promises that it will not happen anymore. I have two children, he is a good father to them, he buys clothes and other things for us.

Why do you think he behaves like this?

-He says that the work is hard, nervous, so he can't control himself.

-Where does he work?

"He works as a security guard in prison, I think that is the reason why he is so angry.

Do your relatives know it?

-They do. They told me to settle it on my own. My family is very kind, My dad never spoke loudly. I did not even know that such things can happen. 
Family problems, security of women from domestic violence in the republic are considered to be difficult and having low chances for a positive outcome in the legal proceedings. Although, according to the lawyer, there are cases when the problem reaches the court and the woman shoots the works in her right for legal protection.

\section{Findings}

Violence against a woman in a Chechen family: why suddenly so much and so often?

An analysis of the problem of domestic violence against a woman in the Chechen society shows that there are general cultural concepts in the national consciousness that reflect typical life fragments of experience in the memory of a person that are taking social and cultural significance. They are often triggers of domestic violence, according to our observations. First, a significant part of men (young people of 25-35) work in military institutions of the republic, where violent hierarchical subordination which includes rudeness, humiliation, insults and threats takes place, according to their own testimony.

It strongly affects the mental foundations of a Chechen male subculture, which under no circumstances would have tolerated such things, if he had a better job with a similar salary rate.

House is the place where he is obeyed, respected and everyone depends on him. The aggression, which was not put to use, manifests itself for an insignificant reason: he works off his bad temper on his wife. Secondly, an enormous gap of income between the "local elite" and the rest of the population causes inferiority complex, hence the financial misfortune is the reason of frequent aggression outbursts in a family. Thirdly, women have become more economically successful, more mobile, they have adapted to the unsteady economy and unemployment. Men, mostly, have been marginalized, they are more conservative, tied to the formal status, it is difficult to fit psychologically into the sociopolitical landscape of the republic, often, and this type of men becomes aggressive in a family.

A social portrait of a male abuser in a family, according to our observations and testimony of women in polls, is this: illiterate, his childhood or adulthood coincided with post-war devastation. He knows poorly the Adat regulations, which dictate the behavioral practices of men in a family. He prays, observes a fast (Uraza), but is barely familiar with the ideology of Islam. In public debates about the place of a man and a woman, he makes his arguments from the position of power, strength, man's rights and submission of a woman to him in every respect. "Her business is to take care of children, at home, she will know her place, then no one will touch her" is a generalized judgment of a significant part of men about the violence against a woman in a family. At the same time, almost no man wants to publicize his aggressive behavior. Therefore, a secondary threat to a woman after violence is the demand to be silent about the violence. This generalization does not mean that there is no violence in families with educated and intelligent men; we only state that gender-based violence prevails among the designated type of men.

\section{Why is a woman silent about violence?}

Firstly, the set of speech and language markers of men represents the discursive verbalization of the dominant ideology in the republic. Television, local media, representatives of the clergy make up a portrait of a woman who is patient, sacrificial, pleasing, forgiving. Its main task is to save the family at any cost. 
Secondly, the public consciousness, which continues to live in accordance with the Adat and in many respects sticks to them, is extremely disapproving of the physical violence of a man against a woman. Fearing to "dishonor" her husband, the woman is silent about her situation.

Thirdly, when the problems of the family become the subject of discussion in public, at Muftiyat (religious institution) or at court, the relatives of the woman, to defend her from violence, take her home, but without children. Firstly, according to the Adat, the children are often owned by father, secondly, relatives are often against raising "the children of the abuser" in their home if the father's side agrees to give the children back to the mother during the divorce. Therefore, a woman at any cost does not publicize the violence from her husband. Her arguments are: she is afraid of the "shame" of public opinion, is deprived of children, the family is falling apart.

Fourthly, she often has nowhere to go and no financial support: she is not ready to give up the children, and she has no money to support them (this is if she can take the children).

Fifth, she sometimes gets used to violence. She seeks the reasons of the problems in herself, in her behavior and even more adapts to humiliation. Paradoxically, the more a woman is ready to come to terms with a situation of violence, the more she provokes violence from a man. (From interview materials)

Sixth, she is ashamed, she is not ready to take the problem out of the house, she does not believe that the problem has a solution.

\section{Traditional social institutions}

\section{Adat and gender-based violence.}

Sociocultural context. In the Adats it is considered to be unworthy of a man to beat and humiliate a woman. "If you are not happy with your wife, send her home. A self-respecting man will not raise his hand on a weak woman, knowing that she cannot fight back."

The essential context. A woman, no matter how long she has been living in marriage, is considered to be an "alien" woman belonging to a different clan. Thus, her resentment, humiliation, especially assault, has been regarded as a challenge to her clan. Engaging into a dispute with her clan has been considered to be extremely troublesome, difficult, and painstaking from all sides: the members of both woman's and man's families would be involved in the dispute. It turned out that the conflict within the family in the form of violence against a woman would expand to the boundaries of the relationship between the two clans of both sides. Needless to say that the woman in every possible way would avoid such a clash in order "not to publicize" the problems of the family.

With the gradual disintegration of the kinship relationship, the social protection of the woman by her clan members began to decline. Although today, if a woman has brothers or powerful relatives, incidents of domestic violence are very rare. If such facts happen, then the relatives of the woman solve them in an ultimatum way (using pulls with influential people as a lever of pressure on the abuser.)

The institutionalization of Islamic law in the form of Sharia courts in the republic, regulating mainly family and marital problems, necessitates reconsidering the gender dimension of conflicts in the family.

The difference between semantic and legal accents in the traditional law (Adat) and the Sharia regarding the permissibility of physical punishment of woman by her husband causes confusion and ambiguity in interpretations, which is complicated by the parallel functioning of these two legal norms in the republic. If the Adats the permissibility of 
physical punishment of a wife is disapproved, then in Islam there are assumptions of her physical punishment, but with considerable reservations.

At the same time, a part of Muslim theologians believes that the statement about the possibility of physical punishment of a woman by a man is the wrong semantic interpretation of certain words in the Quran. So, Dr. Jamal Badavi, in his book "Gender Equality in Islam" (Jamal Badaw, 2012i), writes that many Muslims, more often due to their ignorance, quote the 34 th verse of the $4^{\text {th }}$ surah of the Quran as proof of the superiority of men. "The Quran does not affirm anywhere that one gender is superior. Some mistakenly translate the term "Qivama" (Quran, 4:34) as "superiority," whereas in fact it implies a higher degree of responsibility." Therefore, the generalization of this concept to the "innate superiority" of a man over a woman is inept - the researcher says. Our research confirms that it is not due to the of religiosity in the public consciousness that increases domestic violence, but a primitive, and often speculative interpretation of the gender normative foundations of the Quran by individual theologians, creates in the public discourse the "legitimacy" of domestic violence.

It reflects the attribute of man's power in contrast with a significantly decreasing possibilities for woman's resistance. Young people often take the position of the gender hierarchy in the family too literally, and even students express extremely radical opinions. Here are the statements of the 4th year student of ChGU named Rustam (name changed).

"In Islam it is said that a woman should not even go to her parent's house without her husband's permission. I know the situation when my wife spent two weeks at the deathbed of her sick father, but her husband asked her to come home for a week, and she refused. Then he divorced her. After a while, her father died. So she was left alone with no father and no husband. She should have obeyed her husband, I think he did rightly." Unconditional submission to husband is a dominant thesis today among young people, both boys and some girls. Many young girls are sure that the husband has the right to regulate everything in her life: where she goes, for how long, with whom, what she wears, what color and the length of her dress. ("In Islam it is said that I have to obey him in everything, he is my master." - this is a common opinion of some young women. But women have an extremely negative attitude towards physical violence. At the same time, they are seek all possible ways to stay in the family, if they have common children. In general, young men are confident that they are structurally and culturally prescribed a dominant role in society and the family. And although violence is an unworthy deed for a man, a woman often provokes the violence herself, they say. He is an agent of law and his wife's destiny is in his hands. (At the same time, they ardently refer to Islam).

We suppose that one of the reasons for the distorted interpretation of gender roles with man's domination over a woman with reference to the Quran is a difficult period of the formation of institutional mechanisms of socialization in the framework of Islam.

Legal religious institutions are at the stage of formation and their staff policy raises many questions. Hence the problem of contradictory interpretations of such fundamental questions of family-marriage relations by the Muftiyat spokesmen as: with which parent, under what conditions and from what age must children be brought up when after their parents' divorce? What is the material share of a woman under the Sharia divorce? Who is to collect the material and moral damage caused to a woman when her husband beats her, what is the sum? It is important to take into account the fact that the public consciousness, to a large extent, living according to the norms of the Adat, poorly possessing the Sharia legal system, confuses many fundamental points in matters of marriage and family in general and gender-based violence in particular. The weak and fragmented functioning of 
Russian legislation in matters of family and marriage relations in the republic along with such a "traditional legal landscape" remains generally on the outskirts of the legal sphere.

Securing the legal protection of a woman within the framework of Russian legislation becomes extremely problematic in the context of pluralism of traditional legal practices. According to the lawyer Amina Isaeva, the pressure of husband's relatives, threats of physical elimination of the victim, if she puts her husband in jail, are very frequent. At the very last moment a woman breaks down and gives a different testimony. And if there are children, it is generally a clash of entire clans. As a result, she remains the loser: she gave publicity to a family problem, could not endure the blackmailing and put up with the situation, an in the end, she did not save the family - it is impossible to live with her husband after all that. "But children are those who suffer the most. Very few people think about them. Therefore, we always warn women of the risks associated with the courts. But there were several cases in practice in the last 5 years, when a woman was able to imprison her husband, but these were just radical things - he broke her ribs, etc., " said the lawyer (Valunkov, 2017).

Thus, under the prevailing pluralism of the traditional legal system in the form of the Adats and the Sharia, as well as the Russian laws, many controversial regulatory practices are being implemented today, the complexity of which cannot be reduced only to the imbalance of the legal system towards traditionalism. We are talking about serious problems of legal and social protection of women within the family. We are witnessing an ever-increasing legal demand in public consciousness for a "fair Sharia decision" of a woman's destiny and her children, her right for moral and psychological rehabilitation. This indicates the presence of a certain religious resource regulatory system in a society which is capable of providing some level of everyday security for women in the family.

While analyzing the problem of violence against women, it is important to differentiate the culturally conditioned oppression of women by men and the way how social institutions react to it. The role of the Muftiyat as a spiritual institution, under the conditions of today's Chechnya, has an influence on many spheres of society, especially on family and marriage relations, but when it comes to solving the gender-based violence, the Muftiyat prefers to use only moral suggestion. They talk with the abuser, call his relatives to the Muftiyat only to shame them.

According to the avowal of an Islamic Institute teacher, all these admonitions are of a recommendatory nature and have no legal effect. In extreme cases when a woman is blackmailed by her husband's relatives with children, they appeal to the Head of the Republic. In that case, the problem is solved with administrative pull.

\section{Conclusion}

- The legal standards functioning in the republic (the Russian law, the Adats and the Sharia), due to their simultaneous functioning, are ineffective in solving problems of gender-based violence.

- Public organizations of the republic are trying hard in order to attract public attention to the social and legal protection of women. But they are also involved in the structure of the institutional system, wherein the dominance of the male subculture is absolute.

- Objectification of the problem stumbles upon a strong mechanism of resistance to cultural and religious practices that consider violence as a particular manifestation of male incontinence. Thus, the study of this problem, and moreover, the articulation of the results in public, is considered as an attempt to "discredit the Chechen society". 
- In the public consciousness, despite its rejection of violence as a whole, woman's patience and silence are raised to the status of her virtue, good upbringing, wisdom, and the ability to save her family at any cost.

- It must be admitted that there are quite a few women in the Chechen society who are able to protect themselves from violence, with a developed sense of self-esteem and their number is growing. The value shift that occurs in the minds of some women complicates the possibility to "fit" into the "normative plots" of family-marriage relations, regulated by a set of rules and standards, wherein a woman has incomparably more responsibilities than rights.

- The representation of the infallibility of the male role in social discourse and life practices allows us to speak about a specific cultural model which is forming. In this model, the male dominance in public discourse is "legitimized" by the religion and any attempt of alternative interpretation is considered as a protest against the foundations and values of the Adats and Islam.

The victims of violence rarely resort to Russian laws, and the standards of the Adat and the Sharia appeal mainly to kindred relationship in solving problems. The decision to solve the problem of gender-based violence with the trial of relatives often deprives the woman of her children. Therefore, silence about domestic violence is the most common reaction of women's protection in the Chechen society.

Thus, the sociocultural context of the Adat and the Sharia does not approve of man's violence against women in the family and cannot be interpreted as an ideological and cultural indulgence for men to commit violence. But a superficial, formal understanding of traditional legal institutions, as a claim to a renewed national and religious identity, causes confusion in the public consciousness and social impotence over specific issues of public and private life.

The falsely imposed actualization of the concepts, non-existent in everyday life of the majority of the citizens of the republic, creates a simulacrum reality, while the very life of people, the real motivation of their actions, remains ousted beyond the limits of reflection, which is to be the subject of analysis.

\section{References}

1. S.A. Anisimov, Female violence as an attribute of the destruction of family relations, The dynamics and inertia of reproduction of the population and the replacement of generations in Russia and the CIS. Sociologists and the history of the reproduction of the population of Russia, Yekterenburg, 1, 159 (2016).

2. D. Badawi, Equality of genders in Islam, (2018). Information on http://baznica.info/article/nasilie-v-korane/ (date of reference 17.10.2018)

3. M. Bruckner, Violence in the family: local actions - international problem, Journal of Social Policy Studies, 7(2), 261 (2006)

4 U. Valunkov, the Chechen Divorce, (2019). Information on https://takiedela.ru/2017/08/razvod-po-chechenski/ (date of reference 17.05.2019)

5. G. Garfinkel, Studies in the routine grounds and everyday activities, Sociological Review, 2(1), 59 (2002)

6. M.A. Laktionova, Gender-based violence as a sociocultural phenomenon: stating the problem, Bulletin of the Maikop State Technological University,4, 37 (2010) 
7. A.V. Komarov, The Adats and legal proceedings on them. Collection of information "Caucasian Highlanders" (Mitpo, "Adir", Moscow, 1992)

8. L.U. Kurbanova, The impact of transformational processes on the social well-being of women (based on sociological research among women of the North Caucasus), European Journal of Social Sciences, 6, 403-405 (2016)

9. M. Khatueva, From an interview with a psychologist on individual consultations. ANO "Women for Development" in the Chechen Republic, (2019). Information on http://womenfd.com/ (date of reference 29.06.2019).

10. E. Lazarev, In accordance with the laws of the mountains? How the war affected the balance of law, the Sharia and the common law, (2019). Information on https://youtu.be/zNvknviNESw (date of reference 17.05.2019)

11. S. Sirazudinova, "I cannot say": to the problem of domestic and sexual violence in the republics of the North Caucasus, Woman in Russian Society, 4 (85), (2017)

12. T.V. Shipunova, Aggression and violence as elements of sociocultural reality, Sociological studies, 5, 69 (2002) 